\title{
PERBANDINGAN SISTEM RAINWATER HARVESTING DI KOTA DAN DESA SEBAGAI ALTERNATIF MENGATASI KEKERINGAN (Studi Kasus Desa Krajan Timur dan Desa Panduman, Kabupaten Jember)
}

\author{
Retno Utami Agung Wiyono' ${ }^{1)}$, Entin Hidayah ${ }^{2)}$, Fahir Hassan ${ }^{3)}$, \\ Fista Pebriyanti ${ }^{4}$, Alfiati Ningsih" \\ 1, 2, 3, 4, 5) Jurusan Teknik Sipil, Universitas Jember \\ Jl. Kalimantan 37 Kampus Tegalboto Jember \\ Email: retnoutami@unej.ac.id ${ }^{1)}$,entin.teknik@unej.ac.id ${ }^{2}$, fahirhassan@unej.ac.id ${ }^{3)}$
}

DOI: http://dx.doi.org/10.29103/tj.v11i1.420

(Received: December 2020 / Revised: February 2021 / Accepted: March 2021)

\begin{abstract}
Abstrak
Air adalah sumber daya yang terus dibutuhkan manusia. Dengan menggunakan sistem Rainwater Harvesting RWH), air hujan dapat dimanfaatkan untuk memenuhi kebutuhan domestik. Penelitian ini tidak hanya membahas potensi air yang dapat dimanfaatkan dari sistem RWH yang ada pada satu lokasi saja, akan tetapi mempertimbangkan dua lokasi yang merupakan lokasi yang lebih padat penduduk dan dikategorikan sebagai wilayah kota (Desa Krajan Timur, Sumbersari) dan lokasi yang lebih jarang penduduknya dan dikategorikan sebagai wilayah desa (Desa Panduman, Jelbuk). Dalam penelitian ini digunakan beberapa data yaitu peta lokasi, data curah hujan, dan data kebutuhan air penduduk. Untuk mengetahui kebutuhan air dan sumber air yang digunakan penduduk sehari-hari, dilakukan survey kepada masyarakat yaitu 20 rumah di wilayah kota dan 20 rumah di wilayah desa. Perhitungan potensi air dari sistem RWH dilakukan dengan metode F. J. Mock menggunakan debit andalan 50\%. Dari studi ini diperoleh hasil bahwa pada 20 rumah di wilayah kota, sistem RWH berpotensi menghasilkan air sejumlah 3,168 liter/bulan sampai 31,825 liter/bulan. Adapun pada 20 rumah di wilayah desa, potensi air dari sistem RWH pada setiap rumah berkisar antara 15,090 liter/bulan sampai 33,952 liter/bulan. Potensi air tersebut dapat memenuhi seluruh kebutuhan air pada 20 rumah di desa dan 17 rumah di kota, serta dapat memenuhi $44 \%$ sampai $72 \%$ kebutuhan air pada 3 rumah di wilayah kota.
\end{abstract}

Kata kunci: Rainwater harvesting, kebutuhan air, kesetimbangan air, kota, desa

\begin{abstract}
Water has always become a vital resource that is needed by a human being. Rainwater may play an essential role as a domestic water supply by rainwater harvesting system. This study compares potential rainwater harvested at two locations considered an urban area with higher population density and a rural area with lower population density. The studied urban area and rural area are Desa Krajan Timur, Sumbersari and Desa Panduman, Jelbuk, respectively. Several data utilized in this study are location maps, precipitation data, and water needs data. Surveys are conducted by interviewing twenty residences in each urban and rural area to obtain water needs and water sources data. Water harvested potential was calculated using F J Mock method. The
\end{abstract}

Perbandingan Sistem Rainwater Harvesting di Kota dan Desa Sebagai Alternatif Mengatasi Kekeringan (Studi Kasus Desa Krajan Timur dan Desa Panduman, Kabupaten Jember) - Retno Utami Agung Wiyono, Entin Hidayah, Fahir Hassan, Fista Pebriyanti, Alfiati Ningsih 
study results showed that rainwater harvesting system in 20 houses in the urban area could produce 3,168 liters/month until 31,825 liters/month of water. While the rainwater harvesting system in 20 houses in the rural area could produce 15,090 liters/month until 33,952 liters/month of water. The harvested water could fulfill all water needs in 20 houses in the rural area, 17 houses in the urban area, and $44 \%$ until $72 \%$ of water needs in 3 houses in the urban area.

Keywords: Rainwater harvesting, water needs, water balance, urban area, rural area

\section{Latar Belakang}

Air merupakan sumber daya alam yang sangat penting dan mendesak bagi kehidupan manusia. Dengan semakin padatnya jumlah penduduk, kebutuhan akan air bersih semakin bertambah. Dengan berkurangnya sumber-sumber air, terjadinya kekeringan, musim hujan dan kemarau yang tidak menentu, dan tingkat pencemaran air sungai yang semakin tinggi, kebutuhan akan adanya sumber air yang baru menjadi hal yang tidak bisa ditunda.

Salah satu sumber air yang saat ini mulai dipertimbangkan untuk digunakan adalah air hujan. Air hujan merupakan sumber air yang sangat berpotensi untuk dikembangkan. Akan tetapi, air hujan seringkali terbuang langsung ke saluran drainase sampai ke laut. Padahal, air hujan masih bisa dimanfaatkan dengan menggunakan sistem pemanenan air hujan (Rain Water Harvesting / RWH). Dengan memanfaatkan atap bangunan dan menyalurkannya ke dalam tampungan, terciptalah alternatif sumber air baru yang dapat digunakan untuk memenuhi kebutuhan air terutama pada saat musim kemarau.

Teknologi RWH bukan merupakan hal baru dalam bidang penelitian sumberdaya air. Berbagai penelitian telah dilakukan untuk mengkaji RWH (A. Rahman, 2017). Pemetaan potensi dan reliabilitas sistem RWH juga telah diteliti di berbagai wilayah di antaranya Mombasa (R. O. Ojwang, J. Dietrich, P. K. Anebagilu, M. Beyer, and F. Rottensteiner, 2017), Meksiko (L. LizárragaMendiola, G. Vázquez-Rodríguez, A. Blanco-Piñón, Y. Rangel-Martínez, and M. González-Sandoval, 2015), (G. Sámano-Romero, M. Mautner, A. Chávez-Mejía, and B. Jiménez-Cisneros, 2016), UK (P. Melville-Shreeve, S. Ward, and D. Butler, 2016), Italia (L. Liuzzo, V. Notaro, and G. Freni, 2016), China (X. Liang and M. P. van Dijk, 2016), Australia, Jerm, Srilangka, Thailand, Singapura, Jepang, Korea Selatan (W. Widayat and N. I. Said, 2014), Malaysia, Vietnam, dan Portugal (Y. R. Chiu, K. Aghaloo, and B. Mohammadi, 2020) Bahkan sistem RWH juga mulai dinilai berpotensi sebagai salah satu alternatif solusi dalam mitigasi banjir (C. L. Huang, N. S. Hsu, C. C. Wei, and W. J. Luo, 2015) dan berpotensi mengurangi limpasan air drainase (I. Ali, S. Suhardjono, and A. P. Hendrawan, 2017), (E. Lestari, D. Putri, I. W. K, R. Mekar, and A. Kinasti, 2019). Di Indonesia, RWH juga telah mulai dipopulerkan dan dikenalkan sebagai gerakan konservasi sumberdaya air yang dapat dimulai dari skala rumah tangga (Maryono, 2018).

Pada penelitian yang membahas mengenai potensi sistem RWH, mayoritas potensi yang dibahas ialah potensi pada satu lokasi tertentu (M.Kamaludin, 2018), (G. E. Susilo, 2018) Akan tetapi masih sangat sedikit penelitian yang membandingkan antara potensi sistem RWH di dua lokasi. Pada penelitian ini, akan dibandingkan potensi air yang diperoleh dari sistem RWH pada dua puluh

Perbandingan Sistem Rainwater Harvesting di Kota dan Desa Sebagai Alternatif 
rumah yang berada pada dua lokasi dalam Kabupaten Jember yaitu Desa Krajan Timur, Kecamatan Sumbersari yang dkategorikan sebagai wilayah kota dan Desa Panduman, Kecamatan Jelbuk yang dikategorikan sebagai wilayah desa.

\section{Metode Penelitian}

Dua lokasi yang dipilih ialah wilayah kota yang relatif padat penduduk yaitu Desa Krajan Timur, Kecamatan Sumbersari (Gambar 1a) dan wilayah desa yang relatif lebih jarang penduduknya yaitu Desa Panduman, Kecamatan Jelbuk (Gambar 1b). Perbandingan secara kasar mengenai kepadatan bangunan di kedua wilayah tersebut ditunjukkan pada Gambar 1. Desa Panduman, Kecamatan Jelbuk memiliki luas wilayah $20.8 \mathrm{~km}^{2}$ sedangkan Desa Krajan Timur memiliki luas wilayah $1.38 \mathrm{~km}^{2}$.

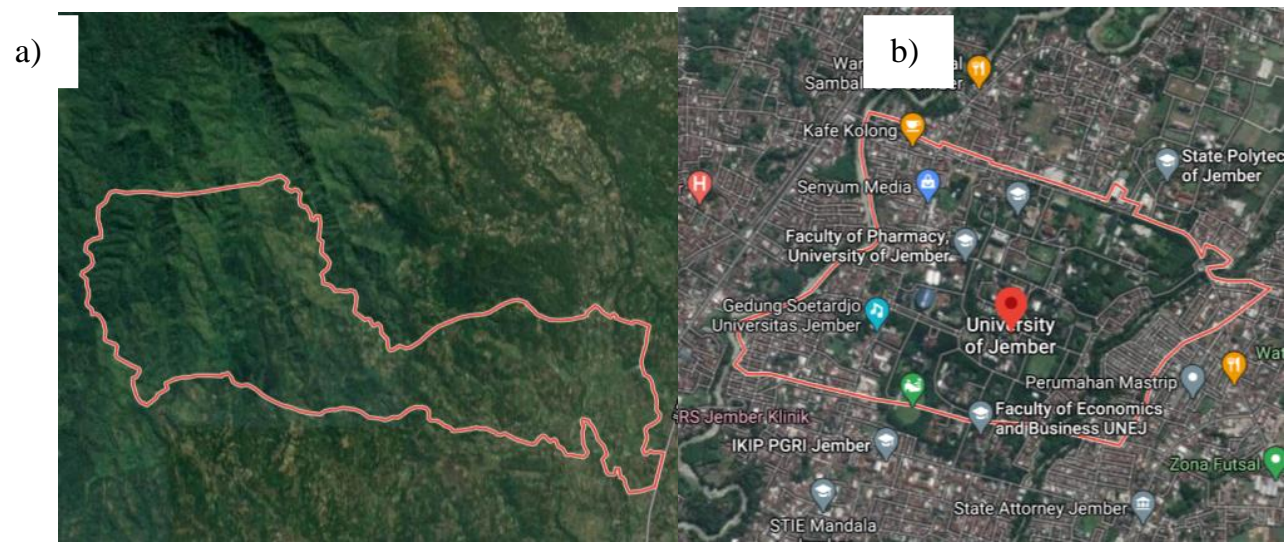

Gambar 1 Lokasi studi: a) Desa Panduman, Kecamatan Jelbuk; b) Desa Krajan Timur, Kecamatan Sumbersari [15]

Kedua lokasi tersebut dipilih sebagai representasi wilayah kota yang padat dengan bangunan (Kampus Tegalboto Universitas Jember) dan wilayah desa yang relatif tidak padat (Desa Panduman, Kecamatan Jelbuk).

Dalam penelitian ini digunakan data peta lokasi. Peta Lokasi digunakan untuk mengestimasi luasan atap dari bangunan di kedua wilayah tersebut untuk melakukan perhitungan volume yang bisa ditampung oleh sistem RWH. Pada penelitian ini, dilakukan pula survey dan inventarisasi data untuk empat lokasi di wilayah Tapal Kuda.

Selain itu, digunakan pula data curah hujan harian dari stasiun terdekat dengan lokasi penelitian. Untuk Desa Panduman Kec. Jelbuk, digunakan data curah hujan harian selama 10 tahun (2010-2019) untuk Stasiun Sukowono, Stasiun Sumber Kalong dan Stasiun Sukorejo. Adapun untuk Desa Krajan Timur Kec. Sumbersari, digunakan data curah hujan harian selama 10 tahun (2010-2019) untuk Stasiun Kottok, Stasiun Wirolegi dan Stasiun Jember.

Data kependudukan juga digunakan dalam penelitian ini. Data yang diperlukan yaitu data populasi penduduk dan data konsumsi air penduduk. Selain mencari dan melakukan estimasi dengan menggunakan data sekunder, dilaksanakan pula survey ke 20 rumah di wilayah desa dan 20 rumah di wilayah kota untuk mengetahui kebutuhan dan ketersediaan air di rumah penduduk tersebut.

Perbandingan Sistem Rainwater Harvesting di Kota dan Desa Sebagai Alternatif Mengatasi Kekeringan (Studi Kasus Desa Krajan Timur dan Desa Panduman, Kabupaten Jember) - Retno Utami Agung Wiyono, Entin Hidayah, Fahir Hassan, Fista Pebriyanti, Alfiati Ningsih 
Adapun tahapan penelitian terdiri atas beberapa tahap. Proses yang pertama dilakukan ialah inventarisasi data. Pada proses ini dilakukan pengumpulan data yang meliputi data peta bangunan pada dua lokasi, data curah hujan dan klimatologi, data sumber air, data populasi penduduk dan data konsumsi air penduduk.

Peta bangunan diambil dari Google Maps. Persil bangunan didigitasi menggunakan perangkat lunak sistem informasi geografis kemudian dilakukan perhitungan luas persil bangunan (Gambar 2). Adapun data sumber air dan data konsumsi air penduduk didapatkan dari hasil survey dan wawancara ke lokasi studi.

Proses pengolahan data curah hujan dijelaskan pada bagian 2.1 sedangkan perhitungan potensi debit air dari system RWH dilakukan dengan menggunakan metode F J Mock yang dijelaskan pada bagian 2.2.

a)

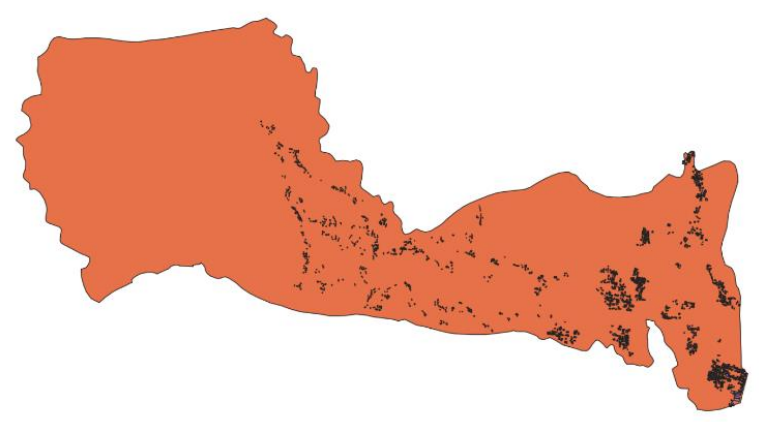

b)

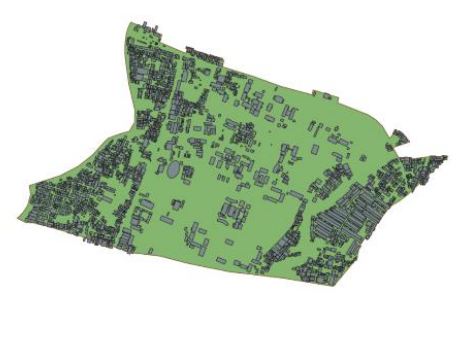

Gambar 2 Persil bangunan pada: a) Desa Panduman, Kecamatan Jelbuk; b) Desa Krajan Timur, Kecamatan Sumbersari

Kebutuhan air di masing-masing rumah dihitung berdasarkan hasil survey yang dilakukan pada 20 rumah di wilayah desa dan 20 rumah di wilayah kota. Pada survey tersebut telah diperhitungkan jumlah anggota keluarga dan kebutuhan air yang diperlukan masing-masing rumah yang terdiri atas kebutuhan air untuk cuci kendaraan, cuci pakaian, mandi dan WC, serta kebutuhan lainnya.

Setelah potensi air yang diperoleh dari system RWH dan kebutuhan air diketahui, dilakukan perbandingan antara potensi air yang mampu diperoleh dengan sistem RWH pada kedua lokasi dengan kebutuhan air pada 20 rumah di wilayah desa dan 20 rumah di wilayah kota.

\subsection{Pengolahan Data Curah Hujan}

Data curah hujan yang digunakan yaitu data curah hujan harian selama 10 tahun dari stasiun terdekat dari lokasi penelitian. Pada wilayah kota digunakan data curah hujan dari tiga stasiun terdekat yaitu, Stasiun Kottok, Stasiun Wirolegi dan Stasiun Jember. Dari data curah hujan harian untuk 10 tahun pada tiga stasiun tersebut, dihitung rata-rata curah hujan harian pada setiap bulannya. Jumlah dari rata-rata curah hujan harian pada setiap bulan dari tiga stasiun tersebut digunakan untuk menghitung debit air dengan metode F J Mock. Adapun rata-rata curah hujan dari ketiga stasiun di wilayah kota ditunjukkan pada Gambar 3. Rata-rata curah hujan dari ketiga stasiun di wilayah kota berkisar antara $367 \mathrm{~mm}$ sampai $688 \mathrm{~mm}$.

Perbandingan Sistem Rainwater Harvesting di Kota dan Desa Sebagai Alternatif Mengatasi Kekeringan (Studi Kasus Desa Krajan Timur dan Desa Panduman, Kabupaten Jember) - Retno Utami Agung Wiyono, Entin Hidayah, Fahir Hassan, Fista Pebriyanti, Alfiati Ningsih 


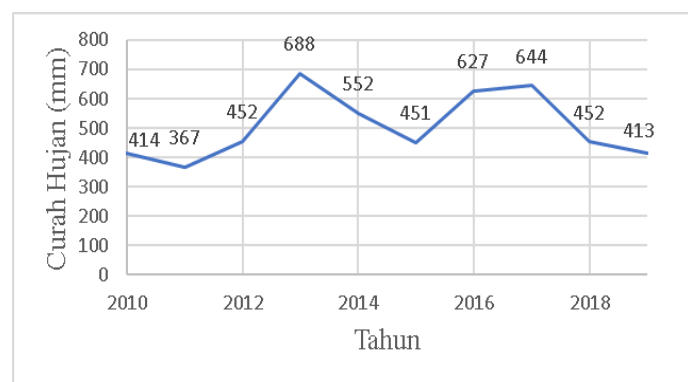

Gambar 3 Grafik rata-rata curah hujan dari tiga stasiun di wilayah kota

Pada wilayah desa digunakan data curah hujan dari tiga stasiun terdekat yaitu Stasiun Sukowono, Stasiun Sumber Kalong, dan Stasiun Sukorejo. Rata-rata curah hujan dari tiga stasiun di wilayah desa disajikan pada Gambar 4. Curah hujan berkisar antara $400 \mathrm{~mm}$ sampai dengan $773 \mathrm{~mm}$.

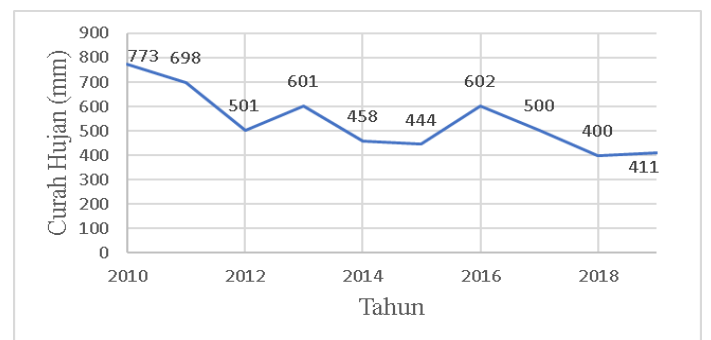

Gambar 4 Grafik rata-rata curah hujan dari tiga stasiun di wilayah desa

\subsection{Perhitungan Debit Air dengan Metode F J Mock}

Dalam menghitung debit yang diperoleh dari sistem RWH, penelitian ini tidak menggunakan metode perhitungan debit menggunakan periode ulang hujan seperti periode ulang 5 tahun yang digunakan pada penelitian lainnya (C. S. Silvia and M. Safriani, 2018), (S. Suhuyanly and W. A. Pranoto, 2019) karena penggunaan periode ulang hujan lebih cocok untuk melakukan perhitungan sistem RWH yang diperuntukkan untuk mengurangi limpasan pada system drainase (I. Ali, S. Suhardjono, and A. P. Hendrawan, 2017).

Perhitungan potensi debit air dari system RWH dilakukan dengan menggunakan metode F J Mock. Data yang digunakan untuk perhitungan metode Mock adalah data curah hujan, data evapotranspirasi, factor karakteristik hidrologi, luas daerah pengaliran, water surplus dan kapasitas kelembaban tanah. Berikut adalah penjelasan masing-masing data yang digunakan berdasarkan KP01 (Kementerian PU Direktorat Jenderal SDA, 2013).

a. Evapotranspirasi Terbatas

Evapotranspirasi terbatas adalah evapotranspirasi actual dengan mempertimbangkan kondisi vegetasi dan permukaan tanah serta frekuensi curah hujan. Untuk menghitung evapotranspirasi terbatas diperlukan data curah hujan 10 tahun (P), jumlah hari hujan (n), jumlah permukaan kering (d) dihitung dengan asumsi bahwa tanah dalam suatu hari hanya mampu menahan air $12 \mathrm{~mm}$ dan selalu menguap sebesar $4 \mathrm{~mm}$, singkapan lahan (m\%) ditaksir berdasarkan peta tata guna lahan dengan asumsi $\mathrm{m}=30 \%$ untuk lahan yang tererosi.

Perbandingan Sistem Rainwater Harvesting di Kota dan Desa Sebagai Alternatif Mengatasi Kekeringan (Studi Kasus Desa Krajan Timur dan Desa Panduman, Kabupaten Jember) - Retno Utami Agung Wiyono, Entin Hidayah, Fahir Hassan, Fista Pebriyanti, Alfiati Ningsih 
Secara matematis evapotranspirasi dirumuskan sebagai berikut:

$$
\begin{aligned}
& \Delta E=E p m \frac{m}{20}(18-n) \\
& \mathrm{E}_{\text {actual }}=\operatorname{Epm}-\Delta E
\end{aligned}
$$

dengan:

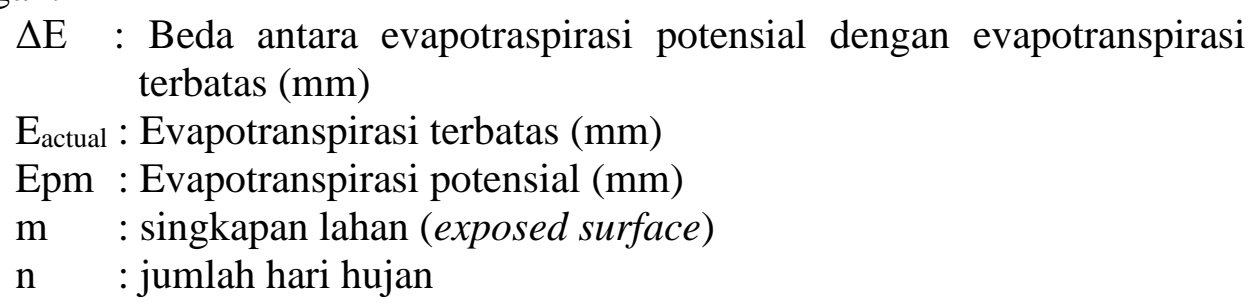

b. Faktor Karakteristik Hidrologi

Dangan asumsi bahwa seluruh daerah studi ialah daerah lahan pertanian yang diolah dan tererosi, maka diagunakan asumsi faktor $\mathrm{m}=30 \%$.

c. Luas Daerah Pengaliran

Luas daerah pengaliran yang digunakan dalam penelitian ini adalah luas atap bangunan yang telah didigitasi pada wilayah kota dan desa dari Gambar 2. Seluruh luas atap pada wilayah kota (Desa Krajan Timur) ialah $0.429 \mathrm{~km}^{2}$ sedangkan pada wilayah desa (Desa Panduman) ialah $0.295 \mathrm{~km}^{2}$.

d. Water Surplus

Water Surplus didefinisikan sebagai curah hujan (P) yang telah mengalami evapotranspirasi terbatas ( $\mathrm{E}_{\text {actual }}$ ) dan mengisi soil storage (SS). Water Surplus secara langsung berpengaruh pada infiltrasi/perkolasi dan total run-off yang merupakan komponen dari debit. Persamaan water surplus (WS) adalah sebagai berikut:

$$
\mathbf{W S}=\left(\mathbf{P}-\mathbf{E}_{\boldsymbol{\alpha c t u a l}}\right)+\mathbf{S S}
$$

e. Kapasitas Kelembaban Tanah (SMC)

Soil Moisture Capacity (SMC) adalah kapasitas kandungan air pada lapisan tanah permukaan per $\mathrm{m}^{2}$. Besarnya SMC untuk perhitungan ketersediaan air ini diperkirakan berdasarkan kondisi porositas lapisan tanah permukaan dari DPS. Semakin besar porositas tanah akan semakin besar pula SMC yang ada. Dalam perhitungan ini nilai SMC diambil antara $50 \mathrm{~mm}$ sampai dengan $200 \mathrm{~mm}$. Persamaan yang digunakan untuk menghitung besarnya kapasitas kelembaban tanah adalah:

$$
\begin{aligned}
& \text { SMS = ISMS + P }- \text { Eactual } \\
& \text { WS = ISMS + P }- \text { Eactual }_{\text {SMS }} \text { SM }
\end{aligned}
$$

dengan:

$$
\begin{array}{ll}
\text { Eactual } & =\text { evapotranspirasi actual, } \mathrm{mm} / \mathrm{bulan} \\
\mathrm{SMS} & =\text { simpanan kelembapan tanah, } \mathrm{mm} / \mathrm{bulan} \\
\mathrm{ISMS} & =\text { kelembapan tanah awal, } \mathrm{mm} / \mathrm{bulan} \\
\mathrm{P} & =\text { curah hujan bulanan, } \mathrm{mm} / \mathrm{bulan} \\
\mathrm{WS} & =\text { kelebihan air, } \mathrm{mm} / \mathrm{bulan}
\end{array}
$$

Perbandingan Sistem Rainwater Harvesting di Kota dan Desa Sebagai Alternatif Mengatasi Kekeringan (Studi Kasus Desa Krajan Timur dan Desa Panduman, Kabupaten Jember) - Retno Utami Agung Wiyono, Entin Hidayah, Fahir Hassan, Fista Pebriyanti, Alfiati Ningsih 
Debit setiap bulan yang diperoleh dari perhitungan menggunakan metode $\mathrm{F}$ J Mock diurutkan berdasarkan nilai debit dari terbesar sampai nilai terkecil. Probabilitas kejadian dihitung dengan menggunakan rumus probabilitas Weibull.

Dari hasil perhitungan, digunakan debit andalan 50\% sebagai acuan untuk menghitung potensi debit air dari sistem RWH. Penggunaan debit andalan 50\% ini digunakan dengan mengambil pertimbangan bahwa musim di Indonesia secara umum terbagi dua yaitu musim hujan dan musim kemarau.

\section{Hasil dan Pembahasan}

Hasil yang telah dicapai dalam setiap tahap penelitian serta pembahasan diuraikan dalam penjelasan berikut.

\subsection{Hasil Survey Air Bersih}

Survey telah dilaksanakan pada dua lokasi yaitu: 1) Desa Panduman, Jelbuk; dan 2) Desa Krajan Timur, Sumbersari. Adapun hasil survey yang dilakukan pada 20 rumah pada masing-masing lokasi ialah sebagai berikut.

Lokasi yang dipilih untuk survey di wilayah desa ialah Dusun Sumber Tengah, Desa Panduman, Kec. Jelbuk. Setelah mendapat izin dari kepala desa, kegiatan survey dilakukan dengan cara mewawancarai langsung warga pada daerah tersebut. Rata-rata sumber air bersih pada daerah Dusun Sumber Tengah Desa Panduman Jelbuk ialah sumur. Namun semenjak kekeringan, daerah tersebut hanya menggunakan satu sumber air dari PDAM yang letaknya berada di balai desa. Masyarakat membayar Rp 15.000,- sampai dengan Rp 30.000,- per bulan untuk menggunakan air dari sumber air PDAM tersebut.

Untuk wilayah kota, lokasi yang dipilih untuk survey terbagi pada tiga lokasi yaitu Jl. Jawa, Gang Citra, dan Perumahan Mastrip. Survey dilakukan dengan wawancara langsung dengan warga.

Pada daerah Jl. Jawa, rata-rata sumber air yang digunakan ialah air sumur. Mereka mengakui tidak mengalami kekeringan dengan sumber air ini dan tidak memerlukan PDAM.

Pada Gang Citra, masyarakat mengalami kekeringan. Air sumur tidak keluar, sedangkan PDAM tidak dapat masuk atau mengalir ke daerah tersebut. Mereka mengambil air dari sumur yang berlokasi di bunderan dekat jalan beraspal di wilayah tersebut.

Pada lokasi Perumahan Mastrip, masyarakat menggunakan air PDAM yang dipatok harganya sekitar Rp 45.000,- per bulan dengan bebas menggunakan air sebanyak yang diperlukan, tidak dihitung berdasarkan meteran air pada setiap rumah.

\subsection{Perbandingan Luas Bangunan}

Dalam penelitian ini, telah dilaksanakan proses pengumpulan data dan pemrosesan data persil bangunan pada kedua lokasi. Dari hasil digitasi luasan persil bangunan pada kedua lokasi, diperoleh presentase luas bangunan dan luas wilayah seperti tercantum pada Tabel 1 .

Dari hasil digitasi persil dan luas wilayah, diperoleh bahwa luas wilayah Desa Panduman yaitu wilayah desa $\left(20.81 \mathrm{~km}^{2}\right)$ ialah 15 kali lebih luas daripada luas wilayah kota yaitu Desa Krajan Timur $\left(1.38 \mathrm{~km}^{2}\right)$. Sedangkan luas persil

Perbandingan Sistem Rainwater Harvesting di Kota dan Desa Sebagai Alternatif Mengatasi Kekeringan (Studi Kasus Desa Krajan Timur dan Desa Panduman, Kabupaten Jember) - Retno Utami Agung Wiyono, Entin Hidayah, Fahir Hassan, Fista Pebriyanti, Alfiati Ningsih 
pada wilayah kota $\left(0.430 \mathrm{~km}^{2}\right)$ lebih besar daripada luas persil pada wilayah desa $\left(0.295 \mathrm{~km}^{2}\right)$. Hal ini menunjukkan perbedaan yang signifikan dari segi kepadatan bangunan pada kedua wilayah tersebut. Dengan luas wilayah yang 15 kali lebih luas dari wilayah kota, wilayah desa memiliki luas persil bangunan yang 0.69 kali lebih kecil dari wilayah kota.

Tabel 1 Perbandingan luas area dan luas persil di wilayah kota dan desa

\begin{tabular}{ccrrr}
\hline \multirow{2}{*}{ No. } & \multirow{2}{*}{ Nama Desa } & Luas area & Luas persil & Presentase \\
\cline { 2 - 5 } & & $\left(\mathrm{km}^{2}\right)$ & $\left(\mathrm{km}^{2}\right)$ & \multicolumn{1}{c}{$(\%)$} \\
\hline 1. & Krajan Timur (Kota) & 1.38 & 0.430 & 31.15 \\
\hline 2. & Panduman (Desa) & 20.81 & 0.295 & 1.42 \\
\hline
\end{tabular}

Adapun presentase luas persil terhadap luas area untuk wilayah desa ialah $1.42 \%$ sedangkan untuk wilayah kota ialah $31.15 \%$. Dengan hasil presentase ini dapat jelas dibedakan bagaimana kondisi wilayah Desa Panduman dengan luas area jauh lebih besar, luas persil yang lebih kecil, dan presentase luas persil terhadap luas area yang lebih kecil, dikategorikan sebagai wilayah desa. Adapun Desa Krajan Timur dengan luas area yang jauh lebih sempit, luas persil yang lebih besar, dan presentase luas persil terhadap luas area yang lebih besar, dikategorikan sebagai wilayah desa.

\subsection{Perhitungan Debit Andalan}

Dalam melakukan perhitungan debit andalan, digunakan metode F J Mock. Hasil perhitungan debit bulanan dengan Metode F J Mock untuk wilayah kota ditunjukkan pada Tabel 2.

Hasil perhitungan tersebut kemudian diurutkan dari yang terbesar sampai terkecil kemudian dihitung probabilitasnya. Dari perhitungan tersebut, diperoleh Flow Duration Curve yang ditunjukkan pada Gambar 5.

Tabel 2 Perhitungan debit bulanan dengan metode F J Mock di wilayah kota (m/s)

\begin{tabular}{ccccccccccccc}
\hline \multirow{2}{*}{ Tahun } & \multicolumn{1}{c}{ Ban } \\
\cline { 2 - 12 } & Jan & Feb & Mar & Apr & Mei & Jun & Jul & Agst & Sept & Okt & Nov & Des \\
\hline 2010 & 0.052 & 0.057 & 0.064 & 0.104 & 0.077 & 0.033 & 0.048 & 0.015 & 0.024 & 0.033 & 0.037 & 0.046 \\
\hline 2011 & 0.075 & 0.073 & 0.123 & 0.124 & 0.047 & 0.023 & 0.016 & 0.008 & 0.005 & 0.004 & 0.009 & 0.051 \\
\hline 2012 & 0.098 & 0.094 & 0.124 & 0.085 & 0.076 & 0.027 & 0.016 & 0.009 & 0.006 & 0.020 & 0.038 & 0.115 \\
\hline 2013 & 0.213 & 0.131 & 0.135 & 0.139 & 0.132 & 0.109 & 0.058 & 0.025 & 0.016 & 0.011 & 0.069 & 0.154 \\
\hline 2014 & 0.205 & 0.135 & 0.095 & 0.166 & 0.051 & 0.028 & 0.016 & 0.010 & 0.006 & 0.004 & 0.055 & 0.190 \\
\hline 2015 & 0.116 & 0.120 & 0.172 & 0.113 & 0.061 & 0.028 & 0.016 & 0.009 & 0.006 & 0.003 & 0.029 & 0.076 \\
\hline 2016 & 0.094 & 0.189 & 0.098 & 0.085 & 0.075 & 0.061 & 0.046 & 0.034 & 0.051 & 0.060 & 0.097 & 0.133 \\
\hline 2017 & 0.152 & 0.154 & 0.127 & 0.139 & 0.069 & 0.073 & 0.025 & 0.015 & 0.010 & 0.038 & 0.159 & 0.151 \\
\hline 2018 & 0.228 & 0.213 & 0.098 & 0.091 & 0.032 & 0.020 & 0.011 & 0.007 & 0.011 & 0.003 & 0.002 & 0.066 \\
\hline 2019 & 0.171 & 0.202 & 0.092 & 0.087 & 0.030 & 0.019 & 0.011 & 0.006 & 0.010 & 0.003 & 0.002 & 0.065 \\
\hline
\end{tabular}

Dari tabel tersebut diperoleh nilai debit terbesar terjadi pada bulan Februari tahun 2018 yaitu $0.228 \mathrm{~m} / \mathrm{s}$. Sedangkan debit terkecil terjadi pada bulan Oktober 2018 yaitu $0.002 \mathrm{~m} / \mathrm{s}$. Jika dilihat rata-rata selama 10 tahun, debit terbesar terjadi

Perbandingan Sistem Rainwater Harvesting di Kota dan Desa Sebagai Alternatif Mengatasi Kekeringan (Studi Kasus Desa Krajan Timur dan Desa Panduman, Kabupaten Jember) - Retno Utami Agung Wiyono, Entin Hidayah, Fahir Hassan, Fista Pebriyanti, Alfiati Ningsih 
pada bulan Januari yaitu $0.142 \mathrm{~m} / \mathrm{s}$ yaitu pada musim hujan. Sedangkan debit terkecil terjadi pada bulan Agustus yaitu $0.014 \mathrm{~m} / \mathrm{s}$ yaitu pada musim kemarau.

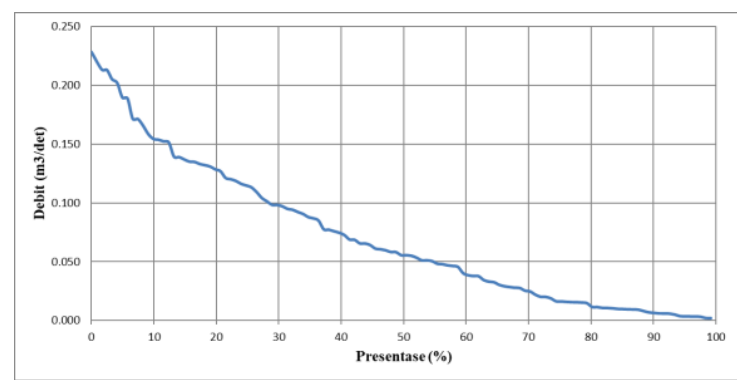

Gambar 5 Flow Duration Curve untuk wilayah kota

Setelah dilakukan perhitungan probabilitas, diketahui bahwa probabilitas $100 \%$ dicapai untuk debit $0.0017 \mathrm{~m} / \mathrm{s}$, probabilitas $80 \%$ dicapai untuk debit $0.0121 \mathrm{~m} / \mathrm{s}$, dan probabilitas $50 \%$ dicapai untuk debit 0.0555 m.s. Dalam penelitian ini, untuk melakukan perhitungan potensi sistem RWH digunakan probabilitas 50\% untuk menghitung debit andalan. Asumsi ini digunakan dengan mempertimbangkan bahwa musim di Indonesia terdiri atas dua musim yaitu musim hujan dan musim kemarau. Kondisi yang ideal ialah jika air pada musim hujan dapat ditampung dengan baik dan digunakan pada musim kemarau.

Hasil perhitungan debit bulanan dengan Metode F J Mock untuk wilayah kota ditunjukkan pada Tabel 3. Hasil perhitungan tersebut kemudian diurutkan dari yang terbesar sampai terkecil kemudian dihitung probabilitasnya. Dari perhitungan tersebut, diperoleh Flow Duration Curve yang ditunjukkan pada Gambar 6.

Tabel 3 Hasil perhitungan debit bulanan dengan metode F J Mock di wilayah desa (m/s)

\begin{tabular}{|c|c|c|c|c|c|c|c|c|c|c|c|c|}
\hline \multirow{2}{*}{ Tahun } & \multicolumn{12}{|c|}{ Bulan } \\
\hline & Jan & Feb & Mar & Apr & Mei & Jun & $\mathrm{Jul}$ & Agst & Sept & Okt & Nov & Des \\
\hline 2010 & 0.151 & 0.127 & 0.088 & 0.106 & 0.083 & 0.068 & 0.034 & 0.016 & 0.055 & 0.043 & 0.059 & 0.094 \\
\hline 2011 & 0.115 & 0.124 & 0.207 & 0.120 & 0.058 & 0.029 & 0.017 & 0.010 & 0.006 & 0.011 & 0.058 & 0.093 \\
\hline 2012 & 0.102 & 0.121 & 0.113 & 0.069 & 0.026 & 0.016 & 0.009 & 0.005 & 0.003 & 0.003 & 0.021 & 0.087 \\
\hline 2013 & 0.120 & 0.093 & 0.087 & 0.060 & 0.065 & 0.055 & 0.033 & 0.013 & 0.008 & 0.006 & 0.067 & 0.093 \\
\hline 2014 & 0.102 & 0.071 & 0.032 & 0.057 & 0.020 & 0.025 & 0.009 & 0.021 & 0.006 & 0.003 & 0.039 & 0.115 \\
\hline 2015 & 0.057 & 0.087 & 0.125 & 0.091 & 0.036 & 0.034 & 0.014 & 0.008 & 0.005 & 0.003 & 0.015 & 0.026 \\
\hline 2016 & 0.085 & 0.113 & 0.078 & 0.050 & 0.045 & 0.053 & 0.016 & 0.010 & 0.017 & 0.033 & 0.090 & 0.094 \\
\hline 2017 & 0.117 & 0.105 & 0.066 & 0.045 & 0.018 & 0.011 & 0.006 & 0.004 & 0.004 & 0.011 & 0.074 & 0.088 \\
\hline 2018 & 0.146 & 0.148 & 0.051 & 0.032 & 0.017 & 0.014 & 0.006 & 0.004 & 0.003 & 0.001 & 0.001 & 0.035 \\
\hline 2019 & 0.158 & 0.150 & 0.052 & 0.033 & 0.018 & 0.014 & 0.006 & 0.004 & 0.003 & 0.001 & 0.001 & 0.035 \\
\hline
\end{tabular}

Dari tabel tersebut, diperoleh nilai debit terbesar terjadi pada bulan Maret tahun 2011 yaitu $0.207 \mathrm{~m} / \mathrm{s}$. Sedangkan debit terkecil terjadi pada bulan Oktober dan November tahun 2018 dan 2019 yaitu $0.001 \mathrm{~m} / \mathrm{s}$. Jika dilihat rata-rata selama 10 tahun, debit terbesar terjadi pada bulan Januari yaitu $0.115 \mathrm{~m} / \mathrm{s}$ yaitu pada musim hujan. Sedangkan debit terkecil terjadi pada bulan Agustus yaitu $0.009 \mathrm{~m} / \mathrm{s}$ yaitu pada musim kemarau. Untuk rata-rata debit bulanan, maka bulan terjadinya debit yang terbesar dan terkecil ialah bulan Januari dan Agustus, sama dengan yang terjadi pada wilayah kota.

Perbandingan Sistem Rainwater Harvesting di Kota dan Desa Sebagai Alternatif Mengatasi Kekeringan (Studi Kasus Desa Krajan Timur dan Desa Panduman, Kabupaten Jember) - Retno Utami Agung Wiyono, Entin Hidayah, Fahir Hassan, Fista Pebriyanti, Alfiati Ningsih 


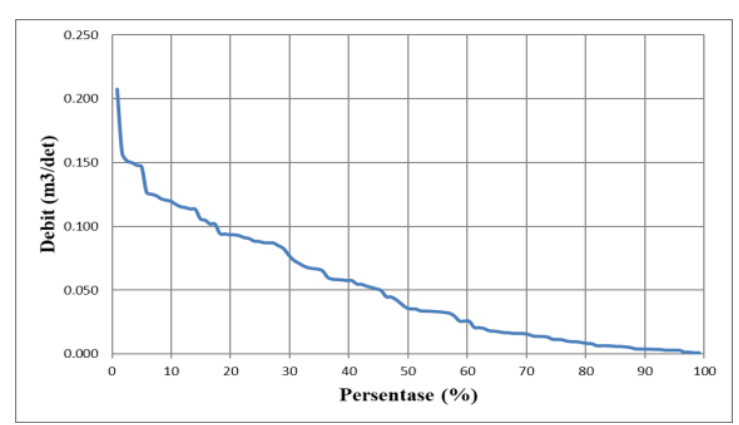

Gambar 6 Flow Duration Curve untuk wilayah desa

Setelah dilakukan perhitungan probabilitas, diketahui bahwa debit 0.0001 $\mathrm{m} / \mathrm{s}$ memiliki probabilitas $100 \%$, debit $0.0083 \mathrm{~m} / \mathrm{s}$ memiliki probabilitas $80 \%$, sedangkan debit $0.0358 \mathrm{~m} / \mathrm{s}$ memiliki probabilitas $50 \%$. Dalam penelitian ini, untuk melakukan perhitungan potensi sistem RWH digunakan probabilitas $50 \%$ untuk menghitung debit andalan.

\subsection{Perhitungan Kebutuhan Air}

Untuk mengetahui kebutuhan air pada wilayah kota dan desa, digunakan data kuisioner yang didapatkan dari hasil wawancara kepada masyarakat pada masing-masing rumah.

Tabel 4 Rata-rata penggunaan air untuk wilayah kota

\begin{tabular}{cccccc}
\hline \multirow{2}{*}{ Nama } & \multicolumn{3}{c}{ Macam Penggunaan (liter/bulan) } & \multirow{2}{*}{ Total } \\
\cline { 2 - 5 } & Kendaraan & $\begin{array}{c}\text { Cuci } \\
\text { Pakaiandi }\end{array}$ & $\begin{array}{c}\text { dan } \\
\text { WC }\end{array}$ & $\begin{array}{c}\text { Kebutuhan } \\
\text { Lain }\end{array}$ & \\
\hline Rumah 1 & 200 & 2400 & 6000 & 500 & 9100 \\
\hline Rumah 2 & 200 & 2400 & 4800 & 500 & 7900 \\
\hline Rumah 3 & 200 & 1800 & 4800 & 500 & 7300 \\
\hline Rumah 4 & 20 & 3000 & 3600 & 500 & 7120 \\
\hline Rumah 5 & 20 & 2400 & 3600 & 500 & 6520 \\
\hline Rumah 6 & 300 & 2400 & 7200 & 500 & 10400 \\
\hline Rumah 7 & 160 & 3000 & 6000 & 300 & 9460 \\
\hline Rumah 8 & 100 & 2400 & 4800 & 300 & 7600 \\
\hline Rumah 9 & 40 & 2000 & 4800 & 200 & 7040 \\
\hline Rumah 10 & 160 & 1800 & 10800 & 300 & 13060 \\
\hline Rumah 11 & 120 & 1200 & 4800 & 500 & 6620 \\
\hline Rumah 12 & 120 & 2400 & 3600 & 150 & 6270 \\
\hline Rumah 13 & 120 & 1200 & 3600 & 150 & 5070 \\
\hline Rumah 14 & 80 & 1800 & 2400 & 150 & 4430 \\
\hline Rumah 15 & 120 & 1200 & 7200 & 150 & 8670 \\
\hline Rumah 16 & 120 & 1200 & 3600 & 150 & 5070 \\
\hline Rumah 17 & 80 & 1800 & 3600 & 150 & 5630 \\
\hline Rumah 18 & 120 & 2400 & 4800 & 150 & 7470 \\
\hline Rumah 19 & 120 & 2400 & 3600 & 150 & 6270 \\
\hline Rumah 20 & 120 & 1800 & 3600 & 150 & 5670 \\
\hline Rata-rata & 126 & 2050 & 4860 & 297.5 & 7333.5 \\
\hline
\end{tabular}

Perbandingan Sistem Rainwater Harvesting di Kota dan Desa Sebagai Alternatif Mengatasi Kekeringan (Studi Kasus Desa Krajan Timur dan Desa Panduman, Kabupaten Jember) - Retno Utami Agung Wiyono, Entin Hidayah, Fahir Hassan, Fista Pebriyanti, Alfiati Ningsih 
Macam penggunaan air pada wilayah kota dan desa yaitu kebutuhan mencuci kendaraan, kebutuhan mencuci pakaian, kebutuhan mandi dan WC, serta pemanfaatan penggunaan air untuk hal lainnya. Penggunaan air pada wilayah kota dan desa dapat dilihat pada Tabel 4-5.

Tabel 5 Rata-rata penggunaan air untuk wilayah desa

\begin{tabular}{cccccc}
\hline \multirow{2}{*}{ Nama } & \multicolumn{4}{c}{ Macam Penggunaan (Liter) } & \multirow{2}{*}{ Total } \\
\cline { 2 - 5 } & $\begin{array}{c}\text { Cuci } \\
\text { Kendaraan }\end{array}$ & $\begin{array}{c}\text { Cuci } \\
\text { Pakaian }\end{array}$ & $\begin{array}{c}\text { Mandi } \\
\text { dan WC }\end{array}$ & $\begin{array}{c}\text { Kebutuhan } \\
\text { Lain }\end{array}$ & \\
\hline Rumah 1 & 240 & 2400 & 3000 & 150 & 5790 \\
\hline Rumah 2 & 20 & 1200 & 2400 & 150 & 3770 \\
\hline Rumah 3 & 100 & 1800 & 2400 & 150 & 4450 \\
\hline Rumah 4 & 20 & 1800 & 1800 & 150 & 3770 \\
\hline Rumah 5 & 20 & 1800 & 1800 & 150 & 3770 \\
\hline Rumah 6 & 200 & 1200 & 3600 & 150 & 5150 \\
\hline Rumah 7 & 200 & 1800 & 3000 & 150 & 5150 \\
\hline Rumah 8 & 20 & 1200 & 2400 & 150 & 3770 \\
\hline Rumah 9 & 200 & 1200 & 2400 & 150 & 3950 \\
\hline Rumah 10 & 20 & 1800 & 5400 & 150 & 7370 \\
\hline Rumah 11 & 100 & 1200 & 2400 & 150 & 3850 \\
\hline Rumah 12 & 100 & 800 & 1800 & 150 & 2850 \\
\hline Rumah 13 & 40 & 800 & 1800 & 150 & 2790 \\
\hline Rumah 14 & 80 & 400 & 1200 & 150 & 1830 \\
\hline Rumah 15 & 80 & 400 & 3600 & 150 & 4230 \\
\hline Rumah 16 & 20 & 400 & 1800 & 150 & 2370 \\
\hline Rumah 17 & 40 & 1000 & 1800 & 150 & 2990 \\
\hline Rumah 18 & 40 & 1000 & 2400 & 150 & 3590 \\
\hline Rumah 19 & 40 & 400 & 1800 & 150 & 2390 \\
\hline Rumah 20 & 20 & 600 & 1800 & 150 & 2570 \\
\hline Rata-rata & 80 & 1160 & 2430 & 150 & 3820 \\
\hline
\end{tabular}

Dari seluruh rumah yang disurvey, presentase penggunaan air yang terbesar ialah mandi dan WC. Setelah itu dilanjutkan dengan keperluan mencuci pakaian, sedangkan yang terkecil ialah kebutuhan untuk cuci kendaraan dan kebutuhan lainnya seperti mencuci piring, menyiram tanaman, minum, dan memasak.

Rata-rata penggunaan air untuk 20 rumah di desa ialah 3820 1/bulan, lebih kecil daripada rata-rata penggunaan air di 20 rumah di kota yaitu 7333.5 l/bulan.

\subsection{Perbandingan antara kebutuhan dan potensi dari RWH}

Pada bagian ini akan dibahas mengenai debit air yang berpotensi untuk dihasilkan melalui sistem RWH pada 20 rumah di wilayah desa dan 20 rumah di wilayah kota. Dalam penelitian ini karena tidak dibedakan antara bulan basah, kering ataupun bulan normal, maka potensi yang dihitung ialah potensi rata-rata berdasarkan 50\% probabilitas dari debit yang dihitung dengan metode F J Mock.

Debit untuk setiap rumah dihitung berdasarkan presentase dari luas persil bangunan pada rumah yang dihitung terhadap luas seluruh persil bangunan yang ada pada desa yang dimaksud.

Dari 20 rumah di wilayah kota, rumah yang memiliki luas bangunan yang paling besar yaitu $95 \mathrm{~m}^{2}$ menghasilkan debit air yang paling besar yaitu 31,824.97

Perbandingan Sistem Rainwater Harvesting di Kota dan Desa Sebagai Alternatif Mengatasi Kekeringan (Studi Kasus Desa Krajan Timur dan Desa Panduman, Kabupaten Jember) - Retno Utami Agung Wiyono, Entin Hidayah, Fahir Hassan, Fista Pebriyanti, Alfiati Ningsih 
Liter per bulan. Sedangkan rumah yang memiliki luas bangunan paling kecil yaitu $10.8 \mathrm{~m}^{2}$ mengahasilkan debit air yang paling kecil yaitu 3,618 Liter per bulan. Dari 20 rumah yang disurvey, rata-rata luas rumah di wilayah kota ialah $55.72 \mathrm{~m}^{2}$ sedangkan debit air yang dihasilkan rata-rata ialah 18,666.18 Liter per bulan.

Dari 20 rumah di wilayah desa, rumah yang memiliki luas bangunan yang paling besar yaitu $108 \mathrm{~m}^{2}$ menghasilkan debit air yang paling besar yaitu 49,383.74 Liter per bulan. Sedangkan rumah yang memiliki luas bangunan paling kecil yaitu $48 \mathrm{~m}^{2}$ mengahasilkan debit air yang paling kecil yaitu 21,947.33 Liter per bulan. Dari 20 rumah yang disurvey, rata-rata luas rumah di wilayah desa ialah $69.15 \mathrm{~m}^{2}$ sedangkan debit air yang dihasilkan rata-rata ialah 31,618.31 Liter per bulan.

Perbandingan antara air yang berpotensi dihasilkan dari sistem RWH dan jumlah presentase yang dihemat ditunjukkan pada Tabel 6 .

Tabel 6 Potensi air dari sistem RWH di wilayah kota

\begin{tabular}{lrrr}
\hline Nama & $\begin{array}{c}\text { Air hujan yang dapat } \\
\text { ditampung bulanan } \\
\text { (liter/bulan) }\end{array}$ & $\begin{array}{c}\text { Kebutuhan } \\
\text { bulanan(liter/bulan) }\end{array}$ & $\begin{array}{c}\text { Presentase } \\
\text { yang dihemat }\end{array}$ \\
\hline Rumah 1 & $16,750.0$ & $9,100.0$ & Memenuhi \\
\hline Rumah 2 & $16,750.0$ & $7,900.0$ & Memenuhi \\
\hline Rumah 3 & $16,750.0$ & $7,300.0$ & Memenuhi \\
\hline Rumah 4 & $8,375.0$ & $7,120.0$ & Memenuhi \\
\hline Rumah 5 & $8,375.0$ & $6,520.0$ & Memenuhi \\
\hline Rumah 6 & $12,663.0$ & $10,400.0$ & Memenuhi \\
\hline Rumah 7 & $15,075.0$ & $9,460.0$ & Memenuhi \\
\hline Rumah 8 & $18,760.0$ & $7,600.0$ & Memenuhi \\
\hline Rumah 9 & $9,212.5$ & $7,040.0$ & Memenuhi \\
\hline Rumah 10 & $3,618.0$ & $13,060.0$ & 72.3 \\
\hline Rumah 11 & $3,618.0$ & $6,620.0$ & 45.3 \\
\hline Rumah 12 & $30,150.0$ & $6,270.0$ & Memenuhi \\
\hline Rumah 13 & $24,120.0$ & $5,070.0$ & Memenuhi \\
\hline Rumah 14 & $31,825.0$ & $4,430.0$ & Memenuhi \\
\hline Rumah 15 & $4,857.5$ & $8,670.0$ & 44.0 \\
\hline Rumah 16 & $31,825.0$ & $5,070.0$ & Memenuhi \\
\hline Rumah 17 & $30,150.0$ & $5,630.0$ & Memenuhi \\
\hline Rumah 18 & $28,475.0$ & $7,470.0$ & Memenuhi \\
\hline Rumah 19 & $31,825.0$ & $6,270.0$ & Memenuhi \\
\hline Rumah 20 & $30,150.0$ & $5,670.0$ & Memenuhi \\
\hline
\end{tabular}

Dari tabel tersebut, dapat terlihat bahwa dari 20 rumah, sistem RWH dapat memenuhi kebutuhan dari 17 rumah yang ada dengan menggunakan probabilitas $50 \%$. Adapun 3 rumah yang memiliki kebutuhan cukup besar dapat menghemat air sebesar 44\%, 45.3\% dan $72.3 \%$ dari total kebutuhan airnya.

Adapun untuk wilayah desa, potensi air dari sistem RWH dipediksi mampu memenuhi kebutuhan air untuk seluruh rumah yang disurvey. Hal ini disebabkan oleh keadaan di wilayah desa (Desa Panduman) yang curah hujannya relatif tinggi dibandingkan dengan keadaan di wilayah kota (Desa Krajan Timur). Selain itu, secara umum luas bangunan pada 20 rumah di wilayah desa lebih luas daripada 20 rumah yang disurvey di wilayah kota.

Perbandingan Sistem Rainwater Harvesting di Kota dan Desa Sebagai Alternatif Mengatasi Kekeringan (Studi Kasus Desa Krajan Timur dan Desa Panduman, Kabupaten Jember) - Retno Utami Agung Wiyono, Entin Hidayah, Fahir Hassan, Fista Pebriyanti, Alfiati Ningsih 
Tabel 7 Potensi debit air dari sistem RWH di wilayah desa

\begin{tabular}{cccc} 
Nama & $\begin{array}{c}\text { Potensi air dari } \\
\text { RWH (liter/bulan) }\end{array}$ & $\begin{array}{c}\text { Kebutuhan } \\
\text { (liter/bulan) }\end{array}$ & Keterangan \\
\hline Rumah 1 & $24,206.2$ & $5,790.0$ & Memenuhi \\
\hline Rumah 2 & $30,179.2$ & $3,770.0$ & Memenuhi \\
\hline Rumah 3 & $18,862.0$ & $4,450.0$ & Memenuhi \\
\hline Rumah 4 & $28,293.0$ & $3,770.0$ & Memenuhi \\
\hline Rumah 5 & $16,975.8$ & $3,770.0$ & Memenuhi \\
\hline Rumah 6 & $16,975.8$ & $5,150.0$ & Memenuhi \\
\hline Rumah 7 & $22,005.7$ & $5,150.0$ & Memenuhi \\
\hline Rumah 8 & $20,748.2$ & $3,770.0$ & Memenuhi \\
\hline Rumah 9 & $26,406.8$ & $3,950.0$ & Memenuhi \\
\hline Rumah 10 & $22,005.7$ & $7,370.0$ & Memenuhi \\
\hline Rumah 11 & $33,951.6$ & $3,850.0$ & Memenuhi \\
\hline Rumah 12 & $18,862.0$ & $2,850.0$ & Memenuhi \\
\hline Rumah 13 & $22,634.4$ & $2,790.0$ & Memenuhi \\
\hline Rumah 14 & $19,805.1$ & $1,830.0$ & Memenuhi \\
\hline Rumah 15 & $19,805.1$ & $4,230.0$ & Memenuhi \\
\hline Rumah 16 & $17,604.5$ & $2,370.0$ & Memenuhi \\
\hline Rumah 17 & $19,805.1$ & $2,990.0$ & Memenuhi \\
\hline Rumah 18 & $19,805.1$ & $3,590.0$ & Memenuhi \\
\hline Rumah 19 & $20,748.2$ & $2,390.0$ & Memenuhi \\
\hline Rumah 20 & $15,089.6$ & $2,570.0$ & Memenuhi \\
\hline
\end{tabular}

Adapun asumsi yang digunakan sebagai dasar menghitung debit pada perhitungan di atas ialah debit andalan $50 \%$ yang dihasilkan dari perhitungan dengan metode F J Mock. Jika digunakan debit andalan 80\%, maka pada wilayah kota, kebutuhan yang terpenuhi seluruhnya ialah 7 rumah sedangkan 13 rumah sisanya terpenuhi sebagian kebutuhan airnya dari sistem RWH. Pada wilayah desa, jika digunakan debit andalan $80 \%$ maka kebutuhan air yang terpenuhi seluruhnya ialah 15 rumah sedangkan 5 rumah terpenuhi Sebagian kebutuhan airnya dari system RWH.

\section{Kesimpulan dan Saran}

\subsection{Kesimpulan}

Dalam penelitian ini telah dilakukan perhitungan mengenai potensi air yang dapat diperoleh dari sistem RWH pada dua puluh rumah yang berlokasi pada wilayah kota yang berada di Desa Krajan Timur, Sumbersari dan wilayah desa yang berada di Desa Panduman, Jelbuk. Pada dua puluh rumah di wilayah kota, potensi air dari sistem RWH pada setiap rumah berkisar antara 3,168 liter/bulan sampai 31,825 liter/bulan. Jika dibandingkan dengan kebutuhan air pada setiap rumah tersebut, jumlah air tersebut dapat memenuhi seluruh kebutuhan air pada 17 rumah dan dapat memenuhi sebagian kebutuhan air (44\% sampai $72 \%$ ) kebutuhan air dari 3 rumah lainnya.

Adapun pada 20 rumah di wilayah desa, potensi air dari sistem RWH pada setiap rumah berkisar antara 15,090 liter/bulan sampai 33,952 liter/bulan. Jika dibandingkan dengan kebutuhan air pada setiap rumah tersebut, jumlah air tersebut dapat memenuhi seluruh kebutuhan air pada 20 rumah tersebut.

Perbandingan Sistem Rainwater Harvesting di Kota dan Desa Sebagai Alternatif Mengatasi Kekeringan (Studi Kasus Desa Krajan Timur dan Desa Panduman, Kabupaten Jember) - Retno Utami Agung Wiyono, Entin Hidayah, Fahir Hassan, Fista Pebriyanti, Alfiati Ningsih 
Penelitian ini menunjukkan bahwa air yang diperoleh dengan menggunakan sistem RWH jika dikelola dengan menggunakan tampungan yang memadai maka dapat memenuhi kebutuhan air yang signifikan pada rumah penduduk. Jika diterapkan dengan baik, sistem RWH ini dapat memberi manfaat besar terutama baik bagi penduduk yang mengalami kekurangan air atau mengurangi beban air PDAM dan air sumur bagi penduduk yang menggunakan sumber air tersebut.

\subsection{Saran}

Penelitian ini dapat dilanjutkan dengan melakukan survey dengan jumlah sampel yang lebih banyak sehingga dapat merepresentasikan seluruh penduduk pada satu desa tertentu. Penelitian juga dapat dilanjutkan dengan melakukan simulasi volume tampungan air sehingga ukuran tampungan air yang sesuai dapat direkomendasikan kepada penduduk yang akan mengaplikasikan metode ini di rumahnya.

\section{Daftar Kepustakaan}

A. Rahman, 2017, Recent advances in modelling and implementation of rainwater harvesting systems towards sustainable development, Water (Switzerland), vol. 8, no. 12, pp. 6-9, doi: 10.3390/w9120959.0

C. L. Huang, N. S. Hsu, C. C. Wei, and W. J. Luo, 2015, Optimal spatial design of capacity and quantity of rainwater harvesting systems for urban flood mitigation," Water (Switzerland), vol. 7, no. 9, pp. 5173-5202, doi: 10.3390/w7095173.

C. S. Silvia and M. Safriani, 2018, Analisis Potensi Pemanenan Air Hujan Dengan Teknik Rainwater Harvesting Untuk Kebutuhan Domestik, J. Tek. Sipil dan Teknol. Konstr., vol. 4, no. 1, pp. 62-73, doi: 10.35308/jts-utu.v4i1.590.

E. Lestari, D. Putri, I. W. K, R. Mekar, and A. Kinasti, 2019, Sosialisasi Pemanfaatan Air Hujan dengan Pembuatan Sumur Resapan Untuk Penanggulangi Banjir / Genangan dan Konservasi Air Tanah di SMP Negeri 8 Menteng Jakarta Pusat," vol. 1, no. 2, pp. 120-127.

G. E. Susilo, 2018, Rainwater Harvesting As Alternative Source of Sanitation Water in Indonesian Urban Area (Case Study: Bandar Lampung City), Rekayasa Sipil, vol. 12, no. 1, pp. 15-21, doi: 10.21776/ub.rekayasasipil/2018.012.01.3.

Google Maps, 2020, Google Maps .

G. Sámano-Romero, M. Mautner, A. Chávez-Mejía, and B. Jiménez-Cisneros, 2016, Assessing marginalized communities in Mexico for implementation of rainwater catchment systems, Water (Switzerland), vol. 8, no. 4, doi: 10.3390/w8040140.

Perbandingan Sistem Rainwater Harvesting di Kota dan Desa Sebagai Alternatif Mengatasi Kekeringan (Studi Kasus Desa Krajan Timur dan Desa Panduman, Kabupaten Jember) - Retno Utami Agung Wiyono, Entin Hidayah, Fahir Hassan, Fista Pebriyanti, Alfiati Ningsih 
I. Ali, S. Suhardjono, and A. P. Hendrawan, 2017, Pemanfaatan Sistem Pemanenan Air Hujan (Rainwater Harvesting System) Di Perumahan Bone Biru Indah Permai Kota Watampone Dalam Rangka Penerapan Sistem Drainase Berkelanjutan, J. Tenik Pengair., vol. 008, no. 01, pp. 26-38, doi: 10.21776/ub.jtp.2017.008.01.03.

Kementerian PU Direktorat Jenderal SDA, 2013, Standar Perencanaa Irigasi, Kriteria Perencanaan Bagian, Perencanaan Jaringan Irigasi KP-01

L. Lizárraga-Mendiola, G. Vázquez-Rodríguez, A. Blanco-Piñón, Y. RangelMartínez, and M. González-Sandoval, 2015, Estimating the rainwater potential per household in an urban area: Case study in Central Mexico, Water (Switzerland), vol. 7, no. 9, pp. 4622-4637, doi: 10.3390/w7094622.

L. Liuzzo, V. Notaro, and G. Freni, 2016, A reliability analysis of a rainfall harvesting system in Southern Italy, Water (Switzerland), vol. 8, no. 1, pp. 1-20, doi: 10.3390/w8010018.

M. Kamaludin, 2018, Perencanaan Rainwater Harvesting untuk Proses Produksi di PT Kereta Api Indonesia (PERSERO), UPT Balai Yasa Yogyakarta, Universitas Islam Indonesia.

P. Melville-Shreeve, S. Ward, and D. Butler, 2016, Rainwater harvesting typologies for UK houses: A multi criteria analysis of system configurations, Water (Switzerland), vol. 8, no. 4, doi: 10.3390/w8040129.

R. O. Ojwang, J. Dietrich, P. K. Anebagilu, M. Beyer, and F. Rottensteiner, 2017, Rooftop rainwater harvesting for Mombasa: Scenario development with image classification and water resources simulation, Water (Switzerland), vol. 9, no. 5, doi: 10.3390/w9050359.

S. Suhuyanly and W. A. Pranoto, 2019, Analisis Potensi Penerapan Sistem Rainwater Harvesting Pada Apartemen Madison Park, JMTS J. Mitra Tek. Sipil, vol. 2, no. 3, p. 179, doi: 10.24912/jmts.v2i3.5822.

W. Widayat and N. I. Said, 2014, Bab 6 Pemanenan Air Hujan (Rain Water Harvesting), in Pengisian Air Tanah Buatan, Pemanen Air Hujan dan Teknologi Pengolahan Air Hujan "Studi Kasus Kota Depok," vol. 1, no. 1, pp. 78-113.

X. Liang and M. P. van Dijk, 2016, Identification of decisive factors determining the continued use of rainwater harvesting systems for agriculture irrigation in Beijing, Water (Switzerland), vol. 8, no. 1, pp. 1-11, doi: 10.3390/w8010007.

Y. R. Chiu, K. Aghaloo, and B. Mohammadi, 2020, Incorporating rainwater harvesting systems in iran's potable water-saving scheme by using a GISsimulation based decision support system, Water (Switzerland), vol. 12, no. 3, doi: 10.3390/w12030752.

Copyright (c) Retno Utami Agung Wiyono, Entin Hidayah, Fahir Hassan,

Fista Pebriyanti, Alfiati Ningsih

Perbandingan Sistem Rainwater Harvesting di Kota dan Desa Sebagai Alternatif Mengatasi Kekeringan (Studi Kasus Desa Krajan Timur dan Desa Panduman, Kabupaten Jember) - Retno Utami Agung Wiyono, Entin Hidayah, Fahir Hassan, Fista Pebriyanti, Alfiati Ningsih 